\title{
The New Literacy Studies and the Resurgent Literacy Myth
}

\section{Harvey J. Graff - The Ohio State University}

The roots of the once "new literacy studies" lay in the 1960s and spread in the 1970s and 1980s. By the early 2000s they were ascendant, with new journals like Literacy in Composition Studies and significant presence in journals, book publications, conference sessions, and course catalogues. The transformation of our understanding of literacy remains far from complete, and fundamental lessons remain to be learned.

Accelerating in the twenty-first century, the same period witnessed the contradictory trend toward an uninformed battle between new literacies and old ones, and the endless proliferation of "multiple literacies." The different bodies of writing and publicity seldom acknowledge each other. To a considerable degree, both the "new" and the "multi-literacies" are marketing campaigns serving corporate profit-making with the promotion of degrees, certificates, courses, consultants, how-to books, and now apps. The conflicts and contradictions are insufficiently appreciated.

I date the foundations of the new literacy studies in the ground-breaking revelations, critiques, and reform proposals in the classic books by Paul Goodman, Growing Up Absurd (1960) and Compulsory Miseducation (1964); Paulo Freire, Pedagogy of the Oppressed (1970); and Jonathan Kozol, Death at an Early Age (1967), among others of that exciting time.

Socially and culturally, there was a relatively small step to a next generation influenced by this literature but more academic. I helped to pioneer it with The Literacy Myth (1979, and subsequent historical works), a study of nineteenth century Canada in comparative perspective. Other authors followed in a series of interrelated books that together created a new field of study and interpretations of literacy in theory and practice.

These constitute a collection of now-classic works across disciplines: psychologists Sylvia Scribner and Michael Cole, The Psychology of Literacy (1981); anthropologist Shirley Brice Heath, Ways with Words: Language, Life, and Work in Communities and Classrooms (1983); anthropologist Brian Street, Literacy in Theory and Practice (1984); and compositionist Deborah Brandt, Literacy in American Lives (2001). Each derived from original research in historical or personal sources or ethnography. Together they form an intellectual foundation with international influence (see, among others, Galvao et al. and Duffy et al.)

From a wide range of approaches and disciplinary orientations, the new literacy studies revised what I designated as "the literacy myth" with concrete research, clear logic of inquiry and interpretation, evidence, comparisons, grounded criticism, new hypotheses, and novel theories. The "literacy myth" dated from antiquity but was articulated and promoted by the "invention" of alphabets, especially the Greek alphabet; the diffusion of the printing press and movable typography; progressive elements of the Renaissance and Enlightenment; nineteenth-century institutional school reforms; and twentieth-century presumptions of the essentialist demands of modern civilization. 
The "literacy myth" presumed the unique and innate power of "literacy by itself."

With no need for documentation, qualification, or definition, literacy held limitless power regardless of individual, collective, or historical context. Literacy was synonymous with progress, illiteracy with stagnation and decay. Remediation for individuals or groups was never presumed likely. When defined at all, literacy meant "reading and writing" with the level of ability unexamined. A later generation would deem literacy in this mythical conception to be essentialist and universalist, a false value, and the confusion of untested inherited ideas with any documented reality. To many, this was an excessively overdetermined form of "modernization theory."

The "mere possession" of literacy was presumed to lead to superiority and advancement. Lack of literacy represented an all but irreparable limitation. Individuals, age groups, gender groups, racial and ethnic groups, tribes, territories, regions, nations, and even continents were labeled essentially as superior or inferior. Literacy and illiteracy, reciprocally, stood as both cause and effect.

As I summarized in 2010, "The Literacy Myth refers to the belief, articulated in educational, civic, religious, and other settings, contemporary and historical, that the acquisition of literacy is a necessary precursor to and inevitably results in economic development, democratic practice, cognitive enhancement, and upward social mobility” (“The Literacy Myth” 635).

By reference to myth, I did not argue that these foundational assumptions were completely false. If that were the case, the "myth" would never have achieved its hegemony. To the contrary, the new literacy studies reformulated our understanding by demonstrating across time and space that literacy always reflects the conditions of its transmission and practice: its specific contexts. Literacy is never a "neutral skill"; it is always historically determined and value laden. It always requires definition and contextualization. (See Graff and Duffy; Graff, "The Literacy Myth”; Graff, Literacy Myths; Graff, Searching for Literacy. See also, for example, Black and Yasukawa; Druick.)

Heath, Street, Scribner and Cole, and Brandt all elaborated my arguments, with separate paths, independent orientations, and their own emphases. Heath introduced us to Trackton, a Black community, and its neighboring, more prosperous, white community. Over the course of a multi-year ethnography, she demonstrated that the presumption of inherited and transmissible deprivation was prejudicial and false. She also revealed the divergent literacy orientations of the two communities.

For Street, literacy is never "autonomous." More often it is "ideological." He showed this in his ethnographic research in Iran and in his critiques of prevailing ideas including those of anthropologist Jack Goody and medievalist Walter Ong.

Cross-cultural experimental psychologists Scribner and Cole compared the dynamics of learning literacy and then using their abilities in a region in Africa. Although they hesitated to unsubscribe from all tenets of literacy's independent attributes, they emphasized the power of context.

In her examinations of different kinds of writing, Brandt documented the importance of values, writing formats and traditions, and practices. Each of us revealed the customs and practices of our own disciplines as well as our shared concerns.

Review of the scholarly and higher-educational domains demonstrates the striking influence of the new literacy studies by the 1980s and 1990s. There was a visible effect on many disciplines and fields within them. These included social history and history of education; educational studies 
including foundations, teaching, and learning; composition studies; and various specializations within each of the social sciences. Publications and curricula support my view.

Yet the replacement of the literacy myth by the new literacy studies was never complete. There is reason to believe that the influence of the new literacy studies has been diminishing. This question demands more complete study.

My review of the past decade or so suggests an undeclared and insufficiently noticed conflict between the new literacy studies and the resurrected myth in the form of proliferating "new literacies" and "multiple literacies." The latter represent Street's autonomous literacies as they evoke the independent power of reading and writing in numerous forms of "literacies" and "skills" in the face of "illiteracies" old and new.

Almost never are these literacies related to foundations in reading, writing, or sometimes arithmetic. Typically, their interconnections and shared contexts of both learning and practice are ignored. Tellingly, their literature almost never cites the new literacy studies' founding and subsequent works. Instead, the literature of the "new," "many," and "multiple literacies" acknowledges few empirical or theoretical studies. The literature reflects the state of this field. It is dominated by lists of "literacies," literally 3,5, 6, 7, 10, 13, and 20 in a rapid online search. The variable listings of "literacies" are extraordinary. These "literacies" have boundless claims; essential or transformative are among the milder ones. The different "literacies" are seldom compared, interrelated, or evaluated. Of course, all "encompass a wide range of skills ... all of which are necessary to succeed."

Many of these proliferating "new literacies" derive from formal organizations founded to promote and sell them, figuratively and literally. Many claim to replace the ever "dying" domain of print. Some repeat the most traditional practices of basic reading and writing (and sometimes arithmetic). Some repeat the outmoded notion of "functional literacy." Most of them resemble illogical, unfounded metaphors rather than reputable literacies. There is no self-awareness, selfcriticism, or admission of multiple contradictions. Despite a half-century of the new literacy studies, these "literacies" proliferate in violation of all its tenets.

Astonishingly, they include reading and writing literacy; functional literacy; writing literacy; prose literacy; document literacy; content literacy; disciplinary literacy; visual literacy; scientific literacy; ecological literacy; numerical literacy; quantitative literacy; data literacy; digital literacy; coding and computational literacy; multimodal literacy; technological literacy; critical literacy; balanced literacy; media literacy; news literacy; informational literacy; game literacy; civic literacy; civic and ethical literacy; multicultural literacy; financial literacy; health and financial literacy; early literacy; developmental literacy; health literacy; mental health literacy; emotional literacy; emotional/physical literacy; agricultural literacy; and recreational literacy.

A sense of chaos, incoherency, and redundancy derives directly from these lists of "many literacies." Among the complications is the blurring of the lines between scholarship and education, on the one hand, and promotion and sales, on the other.

Of the lengthy listing of "literacies," I draw special attention to a "new literacy" recently promoted in a full-page advertisement in the August 3, 2021 edition of The New York Times. This is a form of financial literacy touted as "FL4ALL." In an original formulation that blends elements of 
cheerleading with the work of a flailing ad agency, this awkward promotion dubs financial literacy as FL, a first in the murky annals of "multiple literacies" rhetoric.

FL4ALL derives from a group of banking and financial institutions and one online "education academy," with other corporate "partners." Neither the ad nor the uninformative website shows any familiarity with new literacy studies or multiple literacies. No thought is given to how FL relates to reading and writing or other forms of literacy. FL is never defined. The poorly composed text misappropriates language from the civil rights movement. It makes many boasts about the need and value for FL4ALL. It quickly descends into contradictions. Its promises and prose are a caricature of several hundred years of the literacy myth. Matters of learning and practice do not occur to these marketers peddling a fabricated product.

Writing and composition often straddle the line between literacy as an integrative form of reading and writing in specific contexts of learning and practice, and composition as writing alone. The latter by itself does not qualify as an old or new literacy or one of "many" literacies. This often purposeful confusion is part of a license to exaggerate, promote, and sell writing or composition.

A contemporary example is the Global Society of Online Literacy Educators (GSOLE), according to its website "an inclusive organization of teachers, tutors, and administrators across ranks, all working to improve access to quality literacy education at all levels." They advance this goal through virtual conferences, webinars, and an "online certification" program. This virtual world is solely concerned with writing and composition but chooses "literacy" for its name and its sales pitches.

Readers who think that these problems are scattered or isolated and not a major concern need only to turn to two sources, one popular and the other seemingly scholarly. The first is the magazine Psychology Today. On April 13, 2021, William R. Klemm, Ph.D., "Memory Medic", addressed his own version of "The Literacy Myth." With no familiarity with literacy studies in any recognizable form, his literacy myth is the "under-educated college graduate," because of lack of civics, revisionist history, and confusion of education with indoctrination. The answer is "Socratic teaching." Nothing is defined, including literacy. (See also Peter Toohey, PhD, "How Do You Feel If You Can't Read?"; Dana S. Dunn, PhD, “Thinking about Psychological Literacy: How Psychologically Literate Are You?”; Frank J. Ninivaggi, MD, “Literacy Rampage: So You Wanna Be Literate?”)

The second is the 2020 Routledge Handbook of Literacy Studies, edited by Jennifer Rowsell and Kate Pahl. Across forty-two chapters, it is anachronistic and incoherent. Few contributors are among the most active literacy scholars. The "many literacies" fill chapters that range from "Rural Literacies" and "Urban Literacies" to "Looking Good" and "Immaterializing Literacies."

There is no overall structure, organization, or logic to the collection. Major omissions include the history and comparative anthropology of literacy, two of the foundations of the New Literacy Studies, as well as composition and writing studies and developmental reading studies.

If one presumably crucial chapter symbolizes the problems, it is James Paul Gee's Chapter 2, “The New Literacy Studies." Gee begins, “The New Literacy Studies' (sometimes just referred to as the NLS) names a body of work that started in the 1980s," and ends by contrasting NLS with "A related and slightly later movement, which we can call 'The New Literacies Studies"' (p. 1, 8).

In between, Gee misses critical aspects of the origins, development, and fate of the New Literacy 
Studies. One author at a time serves simplistically and inadequately to cover entire disciplines, for example, Shirley Brice Heath or Brian Street. Historical studies join composition studies in near total exclusion. For example, the only one of my own books that is listed is the 1979 The Literacy Myth, despite the fact that Gee reviewed The Legacies of Literacy (1987) in the Harvard Education Review, Vol. 58, No. 2 (1988), confusing historical with social science studies.

Despite the development and institutionalization of the New Literacy Studies, the gross exaggeration of the power of literacy by itself continues, outside of any meaningful context including foundational reading, writing, and in some cases arithmetic. Often tied to commercialization, the effort to gain credibility by proclaiming anything and everything a "literacy" carries on. The temptations and the appeal are too great. More than four decades after its formal identification, the literacy myth continues to compete with established, trusted research and understanding. 


\section{WORKS CITED}

Black, Stephen, and Keiko Yasukawa. "The Literacy Myth Continues: Adapting Graff's Thesis to Contemporary Policy Discourses on Adult 'Foundational Skills' in Australia." Critical Studies in Education, vol. 55, no. 2, 2014, pp. 1-21, doi.org/10.1080/17508487.2014.904809 Brandt, Deborah. Literacy in American Lives. Cambridge UP, 2001.

Dunn, Dana S. “Thinking About Psychological Literacy: How Psychologically Literate Are You?”

Psychology Today, 21 Sept. 2009, www.psychologytoday.com/us/blog/head-theclass/200909/thinking-about-psychological-literacy.

Druick, Zoe. “The Myth of Media Literacy." International Journal of Communication, vol. 10, 2016, pp. 1125-44.

Duffy, John, Patrick Berry, Michael Harker, Peter Mortensen, Mike Rose, and Amy Wan, with Response by Harvey J. Graff. "Harvey J. Graff, Literacy Studies, and Composition," Conference on College Composition and Communication, 2017, publication pending. Freire, Paulo. Pedagogy of the Oppressed. Herder and Herder, 1970.

Galvão, Ana Maria de Oliveira, Maria Cristina Soares de Gouvêa, and Ana Maria Rabelo Gomes.

"An Interview with Harvey J. Graff and Brian Street." Literacy in Composition Studies, vol. 5, no. 1, 2017, pp. 49-66, doi.org/10.21623/1.5.1.4.

Gee, James Paul. “The New Literacy Studies.” In Rowsell and Pahl, pp. 1-8.

Global Society of Online Educators. Welcome to GSOLE!: Official Site of the Global Society of Online Literacy Educators, gsole.org/.

Goodman, Paul. Compulsory Mis-Education and the Community of Scholars. Horizon, 1966.

---. Growing Up Absurd. Random House, 1960.

Graff, Harvey J., Literacy Myths, Legacies, and Lessons: New Studies on Literacy. Transaction, 2011.

---. Searching for Literacy: The Social and Intellectual Origins of Literacy Studies. Palgrave Macmillan, 2022.

---. The Literacy Myth: Literacy and Social Structure in the Nineteenth-Century City. Academic, 1979.

---. “The Literacy Myth at 30." Journal of Social History, vol. 43, no. 3, 2010, pp. 635-61.

Graff, Harvey J., and John Duffy. "Literacy Myths." Literacies and Language Education: Encyclopedia of Language and Education, edited by Brian V. Street and Stephen May, Springer, 2017, pp. 2-11.

Heath, Shirley Brice. Ways with Words: Language, Life, and Work in Communities and Classrooms. Cambridge UP, 1983.

Klemm, William R. “The Literacy Myth: College is No Guarantee of Literacy." Psychology Today, 13 Apr. 2001, www.psychologytoday.com/us/blog/memory-medic/202104/the-literacy-myth.

Kozol, Jonathan. Death at an Early Age. Random House, 1967.

Ninivaggi, Frank J. “Literacy Rampage: So You Wanna Be Literate?” Psychology Today, 4. Sept 2017, www.psychologytoday.com/us/blog/envy/201709/literacy-rampage-so-you-wanna-beliterate. 
Rowsell, Jennifer, and Kate Pahl, editors. Routledge Handbook of Literacy Studies. Routledge, 2020, doi/10.4324/9781315717647.

Scribner, Sylvia, and Michael Cole. The Psychology of Literacy. Cambridge UP, 1981.

Street, Brian. Literacy in Theory and Practice. Cambridge UP, 1984.

Toohey, Peter. “How Do You Feel if You Can’t Read?” Psychology Today, 3 April, 2015, www.

psychologytoday.com/us/blog/annals-the-emotions/201504/how-do-you-feel-if-youcant-read. 